This is the final accepted version of this paper - please do not cite.

For the final published version, see West-Oram, P.G.N and Widdows, H. "Global Population and Global Justice: Equitable Distribution of Resources Among Countries", Electronic Library of Science (eLS), 2012. URL = http://dx.doi.org/10.1002/9780470015902.a0024140

\title{
Global Population and Global Justice: Equitable Distribution of Resources among Countries
}

\section{Peter West-Oram and Heather Widdows}

\begin{abstract}
Analysing the demands of global justice for the distribution of resources is a complex task and requires consideration of a broad range of issues. Of particular relevance is the effect that different distributions will have on global population growth and individual welfare. Since changes in the consumption and distribution of resources can have major effects on the welfare of the global population, and the rate at which it increases, it is important to establish meaningful principles to ensure a just distribution of resources. In order to establish such principles we must consider the scope of any reproductive rights, and rights to other goods, such as food and health care, as well as examine the extent of duties correlating to those rights. In addition to the impact that distributions of global goods have on the welfare of current generations, it is also important to consider what duties we have, if any, to future generations.
\end{abstract}

\section{Key Words}

- Global Justice

- Reproductive Rights

- Population Ethics

- Environmental Ethics

- Sustainability

- Resource Constraints

- Duties to Aid

- Human Rights

- Population Growth

- Climate Change

\section{Key Concepts}

- Questions relating to global justice are concerned with the justice of international institutions and events; they are also concerned with establishing fundamental moral principles which form the basis of international law.

- Human rights are those rights which are held by all people in virtue of their status as human beings, rather than because of any specific law or in virtue of belonging to a specific group or country.

- The distribution and consumption of resources is important in discussion of global justice since the way in which resources are allocated will have a major effect on human welfare and ability of individuals to enjoy their rights.

- Distributive Justice can be analysed on a range of scales, from the local to the global and deals with questions relating to the distribution of resources and other important goods; these can be things like money, health care, or food, as well as more intangible concepts like freedom and liberty. 
This is the final accepted version of this paper - please do not cite.

For the final published version, see West-Oram, P.G.N and Widdows, H. "Global Population and Global Justice: Equitable Distribution of Resources Among Countries", Electronic Library of Science (eLS), 2012. URL = http://dx.doi.org/10.1002/9780470015902.a0024140

- Environmental sustainability is important in the global justice context because environmental degradation can have severe impacts on human welfare; as such, the sustainability of different types, and rates, of resource consumption will be more or less just, depending on the harm that is caused by it.

- Egalitarianism is the view, common in discussions of justice, that all human beings are morally equal and that as a result, should be given equal moral consideration.

- Prioritarianism is the view in theories of justice that a specific group, for example the citizens of a particular country, or those living in poverty should have their needs prioritised over the needs of other groups.

- Sufficientarianism is the view that justice requires only that everyone has enough and that all people have sufficient resources or are above a specific welfare threshold, contrary to egalitarianism, sufficientarianism is compatible with the existence of unequal distribution of goods.

\section{Introduction}

Many types of issue are raised when one is attempting to determine what is 'just' with regard to population and resource allocation in the global context. In terms of resource allocation a number of questions arise with regard to justice. In particular, with regard to distributive justice, we might question whether it requires that all resources are equally shared. Likewise, we could question whether there are certain kinds of goods, such as health care, which are more important than others and whether providing a sufficient quantity of these goods to everyone is enough for justice. In terms of population, as well as justice issues, we might also examine the extent and nature of reproductive rights; including whether there is an individual 'right' to have a child, or any number of children, or whether individual reproduction should be curtailed. Furthermore, issues of population raise many questions about environmental ethics and sustainability - such as whether population growth is such a threat to human survival - and to the rights of future generations - that extreme restrictions on human population are justified. Finally, there are major questions surrounding the extent of individual freedoms, for example to emigrate or to control one's intellectual property, when exercising those freedoms will cause harm to third parties.

This list is obviously not exhaustive, and we do not attempt to address all of these issues in this chapter. However, this list, incomplete as it is, provides an overview of the kinds of questions in play when talking about issues of global justice and population and illustrates the types of ethical argument used in discussion of these issues. In this chapter we focus only on the following two questions; firstly, what duties to present and future generations apply when we are discussing global population, and secondly, what must we consider when determining the scope of rights to have children, if such rights exist? Together these concerns provide good examples of the kind of ethical concerns which need to be considered when considering global population and justice.

\section{The problem of scarce resources and increasing population}

Before moving on to discuss these two areas of focus we first lay out some key facts and figures with regard to global population and global justice (or more accurately, global injustice). Understanding the actual context of these theoretical questions is crucial to doing ethics and the figures reveal the extent of the problem at hand. While it is true that fertility 
This is the final accepted version of this paper - please do not cite.

For the final published version, see West-Oram, P.G.N and Widdows, H. "Global Population and Global Justice: Equitable Distribution of Resources Among Countries", Electronic Library of Science (eLS), 2012. URL = http://dx.doi.org/10.1002/9780470015902.a0024140

rates have fallen since the 1970s (The United Nations 2011b, p.xi), the global population continues to rise, having reached 7 billion people in October 2011 (Coleman 2011), as does the consumption of natural resources, particularly by the citizens of wealthy countries (Murtaugh and Schlax 2009, p.18). According to the United Nations (UN) if we assume a constant fertility rate, the global population can be expected to exceed 10 billion people by 2050, and to exceed 25 billion by 2100 . Even if we assume a lower (though still high) fertility rate, global population can be expected to exceed 15 billion by 2100 (The United Nations: Department of Economic and Social Affairs 2011, p.xvi). Further, the same report notes that in developed countries currently $22 \%$ of the population is over 60 years of age, and that by 2050 this figure is expected to reach $32 \%$ (2011, p.xv). The expansion of the global population of course brings with it increases in resource consumption and emissions of greenhouse gases, which lead to major environmental upheaval with potentially disastrous consequences for many. Meinshausen et al. (2009) have stated that limiting cumulative carbon emissions since the industrial revolution to one trillion tonnes (or 1000 gigatonnes), limits to $25 \%$ the chance that global temperature will rise by $2^{\circ} \mathrm{C}$ by 2050 (M. Meinshausen et al. 2009, p.1158), whilst emitting up to 1.44 trillion tonnes increases that probability to $50 \%$. Since global emissions between 2000-06 reached 236 billion tonnes, the likelihood that the trillionth tonne threshold will not be met is extremely small (M. Meinshausen et al. 2009, p.1158).

The impact of increased temperature is likely to have a severe effect on many living in low lying countries, and particularly the poor. McMichael et al. have noted that the effects of increased temperatures are likely to have significant impacts on human health, noting that by 2050 the proportion of people who live in areas where malaria is common is likely to rise from $45 \%$ to $60 \%$ of the global population due to increased habitat for malaria spreading mosquitoes (McMichael et al. 1996, p.7). Further, McMichael et al. also note that increases in sea level can lead to the destruction of sources of drinking water, flooding, displacement and crop failure in low lying areas (McMichael et al. 1996, pp.154-157). Increasing the size of the global population also increases the pressure on already limited resources and by doing so imposes even greater hardships on the poorest and most vulnerable members of human society. These figures show the stark reality of the impact that unsustainable resource consumption and population growth can have on the most vulnerable people. In the following section we begin to examine different approaches to responding ethically to these issues. See also DOI: $10.1038 /$ npg.els.0003488.

\section{Global Justice and the Equitable Distribution of Resources}

Having set out the figures the magnitude of the problem of global justice and scarce resources is clear. The question then is what the appropriate ethical response to this issue is. The first issue we will address in our consideration of equitable distribution between resources and current population is what duties we have to the current global population in terms of resource allocation and consumption. ${ }^{1}$

\footnotetext{
${ }^{1}$ Wealthier countries currently consume more far more per person than poorer countries (Murtaugh and Schlax 2009, p.18), contributing to harms already endured by the most vulnerable (McMichael et al. 2003) and further endangering those living in those countries. We should also note that approximately 2.5 billion people live on less than \$2 per day with roughly one billion of those people living on \$1 per day or less (Pogge 2008, p.211).
} 
This is the final accepted version of this paper - please do not cite.

For the final published version, see West-Oram, P.G.N and Widdows, H. "Global Population and Global Justice: Equitable Distribution of Resources Among Countries", Electronic Library of Science (eLS), 2012. URL = http://dx.doi.org/10.1002/9780470015902.a0024140

Many ethicists, and particularly global ethicists (Sen 1999; Widdows 2011), argue for global justice and for global distribution of scarce resources, but, this is not the only possible position to take. For instance, Garrett Hardin has famously argued (Hardin 1974) that we should not be seeking to share resources equally, but should rather attempt to limit population and to preserve the environment for the benefit of future generations. Consequently he argues that there are not global duties to aid the poor, and that presumptions of global equality are false, as well as harmful, and should be rethought (Hardin 1974, pp.561-562).

Hardin rejects presumptions of equality, criticizing both Marxist ideals of responsibility based on ability and Christian demands that we be 'our brother's keeper' (Hardin 1974, p.562), and what he terms the 'spaceship model' which demands frugality in a world (analogised as a spaceship for the metaphor) of limited resources (Hardin 1974, p.561). He suggests that this model - which assumes that because we all share the planet we should share resources - leads to the destruction of resources and allows "misguided idealists to justify suicidal policies for sharing our resources through uncontrolled immigration and foreign aid" (Hardin 2008, p.16). Hardin's 'lifeboat' claim is a development of an earlier argument that commonly owned and shared resources are exploited and unsustainable (Hardin 1968). This he calls the 'tragedy of the commons' (Hardin 1968, p.1244); that without privately owned resources all people simply exploit shared resources as much as they can leading to the destruction of that resource. Examples Hardin uses include the exploitation and pollution of global commons of air, water, and land and fish stocks (Hardin 1968, pp.1245-1247). Thus his claim is that for resources to be protected and sustained into the future and in order that the rights of future generations be protected, resources must first be owned by somebody and second that access to them must be limited to a particular population.

Hardin contrasts the common - and he believes - false view of 'spaceship' ethics; where all should have access and rights to share in common global resource to his own 'lifeboat' model (Hardin 1974, p.561). He argues that we should think of the world not as a shared environment equally sustaining of all, but rather as an ocean scattered with lifeboats. The lifeboats representing the rich countries (which hold about a third of the world's population) are adequately provisioned, and have enough room for all their current passengers. In contrast, Hardin describes the lifeboats representing poor countries as being overcrowded and far less well provisioned than their wealthy counterparts. When passengers of poor lifeboats fall out of their vessel, as Hardin claims happens 'continuously' (Hardin 1974, p.561), the poor swim in the ocean towards the wealthy lifeboats, desperately trying to clamber aboard.

Further, even in wealthy countries, which collectively own $78.98 \%$ of global wealth (Pogge 2008, p.105), wealth is not equally distributed. For example, in the United States roughly $30 \%$ of the nation's wealth has been owned by the richest 1\% since the 1920s (Keister and Moller 2000, p.63). Globally, billions live without access to the most basic facilities and thousands die every day from preventable, treatable illnesses (Pogge 2008, p.222) while the wealthy enjoy opulent, and unsustainable, luxury. We discuss these issues in more detail later in the paper but the mere fact of the persistence of such incredible inequality, and the vulnerability and suffering that it allows, demonstrates the need for considerable analysis of our duties to other people and the rights that are held by the poorest to at least a threshold level of resources and welfare. While the issues of inequality and poverty are exacerbated by population growth, even without any such growth this remains arguably the most important question in the global ethics debate. However, this chapter is not concerned with global justice in general but rather on the context of population. Therefore, this will be our focus for the rest of this section. 
This is the final accepted version of this paper - please do not cite.

For the final published version, see West-Oram, P.G.N and Widdows, H. "Global Population and Global Justice: Equitable Distribution of Resources Among Countries", Electronic Library of Science (eLS), 2012. URL = http://dx.doi.org/10.1002/9780470015902.a0024140

Only in the lifeboats is life sustainable and can resources be accessed, and it is only in wealthy lifeboats that life can be comfortable, however, the lifeboats are nearly at capacity according to Hardin. Those in wealthy lifeboats could share what they have and bring a few more people into the lifeboats, but doing so is allegedly risky for current passengers since doing so would threaten the 'safety factor' of their vessel (Hardin 1974, p.562). According to Hardin, accepting more passengers into wealthy lifeboats would be dangerous, even if those lifeboats currently enjoy extra capacity, as doing so would remove any margin for survival by reducing or eliminating the capacity to respond to crises (such as drought or flood) (Hardin 1974, p.562).

Hardin uses this metaphor to argue that we should not share resources equitably and globally since doing so would mean that '[ $\mathrm{t}$ ] he boat is swamped, and everyone drowns' (Hardin 1974, p.562). Rather, Hardin argues that resources should only be shared within sustainable populations and we should police borders rigorously to ensure that the resources are not threatened. He argues that we should refuse to allow any additions to the lifeboats and set guards at their perimeters. We must, Hardin states, 'be on our guard against boarding parties' (Hardin 1974, p.562). He therefore rejects global approaches to justice as disastrous for all, particularly future generations, since if we allow all refugees from poor lifeboats into rich ones, there will be no lifeboats left, and we will all end up swimming. In Hardin's words "complete justice, complete catastrophe" and his advice to those who feel this is unjust is to "get out and yield your place to others" (Hardin 1974, p.562), rather than to threaten their fellow passengers. Hardin's view of lifeboat ethics is therefore that it is essentially a zerosum game, in which for any one person to benefit, another must lose out. For Hardin, there can be no general increase in welfare, since for a person from a poor lifeboat to benefit; a wealthy person must sacrifice their own good to them.

Hardin's argument is not, thankfully for the global ethicist, a knock down claim. For instance, Betsy Hartmann has argued that Hardin's claim, like that of other adherents of Malthusian population theory, is based on the assumption that the supply of food available is fixed. Indeed, she points out that population growth also expands the work force and encourages innovation, and can have a positive impact on the amount of food available for everyone (Hartmann 1995, p.16). The problem, Hartmann argues is 'not that there are too many people and too few resources, but rather that too few people monopolize too many resources' (Hartmann 1995, p.17). Similarly, it should be noted that Amartya Sen has demonstrated that economic development and social welfare programs, such as the food aid programs which Hardin decries, actually serve to reduce fertility rates, thereby limiting population growth and encouraging further development (Sen 1994, p.72). To return to Hardin's metaphor, providing food aid to overcrowded lifeboats does not increase the number of people onboard, rather it makes the lifeboat bigger, and reduces the rate at which new passengers are added. See also DOI: 10.1002/9780470015902.a0003292.pub2.

As well as considering what justice requires with regard to distributing current resources when examining population it is also important to discuss population control, or reduction and sustainability. The figures set out at the beginning of the chapter and Hartmann's argument in the previous paragraph, show starkly that the problems of scarce resources, and the dire poverty of the majority, are likely to grow with increases in population. Thus, whilst it is important to manage existing global resources more effectively, it is also important to 
This is the final accepted version of this paper - please do not cite.

For the final published version, see West-Oram, P.G.N and Widdows, H. "Global Population and Global Justice: Equitable Distribution of Resources Among Countries", Electronic Library of Science (eLS), 2012. URL = http://dx.doi.org/10.1002/9780470015902.a0024140

consider restricting growth of the global population. Such restrictions could mean that there are fewer demands on scarce resources, enabling greater access by more people, and that issues relating to environmental sustainability and biodiversity are more likely to be addressed. ${ }^{2}$ Failing to consider the implications of accelerating population growth, and the environmental impact of such growth, is extremely foolhardy. We must, therefore, carefully examine issues of population control.

\section{Global Population and Human Rights}

Population control then might seem to be the most obvious method of addressing the problem of scarce resources - as well as being important for other issues of global justice such as the impact that expanding populations have on climate change and environmental degradation which can lead to the depletion of natural resources such as clean drinking water (McMichael 1993, p.319; Barnett and Adger 2003, pp.321-322) - however implementing population control is less easy than one might think. See also DOI: 10.1002/9780470015902.a0020480.

One answer is to impose draconian, and artificial, measures of population control. Unsurprisingly, Hardin is as uncompromising with regard to population control as he is when it comes to the sharing of limited resources. He advocates coercive population control as a means of lessening environmental degradation; the fewer people in the sea the less the threat to the lifeboats, and the fewer people in the lifeboats the more sustainable they are. He argues that populations should be naturally checked by drought and famine and this should not be interfered with. He attributes population growth in part to the misguided giving of aid to the poor, stating that 'Every life saved this year in a poor country diminishes the quality of life for subsequent generations' (Hardin 1974, p.565). To support the claim that international food aid contributes to unsustainable increases in population, Hardin describes a 'ratchet effect' (Hardin 1974, pp.563-564), whereby the provision of food aid to poor countries prevents the reducing effect of drought and famine from imposing natural equilibrium on populations, in effect encouraging unsustainable population growth. He also argues that populations have grown artificially as a result of the distribution of food aid, and that such artificial growth, unrestricted by disaster will allegedly lead to greater disaster in the future, to the inevitable detriment of our descendents (Hardin 1974, p.567). 'However humanitarian our intent' Hardin argues 'every Indian life saved though medical or nutritional assistance from abroad diminishes the quality of life for those who remain, and for subsequent generations'(Hardin 2008, p.23). Therefore, Hardin argues, the provision of aid must cease, and those left 'swimming in the ocean' (Hardin 1974, p.561) must be allowed to drown in order to avoid total catastrophe for all.

However, even for those who advocate population control, there are problems with this picture, particularly when we consider the different use of resources by different demographics. For instance, it matters far more how much each person from a specific group consumes than the number of people in that population. To illustrate, if the total number of individuals in population $x$ is half that of the number of individuals in population $2 x$, but each individual in the former group consumes four times as many resources as their counterpart in the latter group, the total size of each population is of less importance than the total resources

\footnotetext{
${ }^{2}$ Of course, ensuring environmental sustainability provides great benefit to both current and future generations by providing habitable environments for there to be generations in.
} 
This is the final accepted version of this paper - please do not cite.

For the final published version, see West-Oram, P.G.N and Widdows, H. "Global Population and Global Justice: Equitable Distribution of Resources Among Countries", Electronic Library of Science (eLS), 2012. URL = http://dx.doi.org/10.1002/9780470015902.a0024140

consumed. ${ }^{3}$ For example, a recent (2009) study from Oregon State University concluded that on average a child in the US in fact has a long-term effect on raising carbon emissions that is 136 times higher than a child in Bangladesh (Murtaugh and Schlax 2009, p.18). Hence there is not necessarily a direct correlation between higher numbers of people and a greater detrimental effect on the environment: the economic conditions of different societies and their rates of consumption are far more important. To return to Hardin's example in light of this information, it might be argued that perhaps it is not those in the sea who should have their numbers curtailed but those in the lifeboats. If our concern is for resource depletion then, based on the figures from the Murtaugh and Schlax study, we should focus our efforts not on the poorest and most vulnerable, but on those who consume the most - the passengers of the most comfortable lifeboats; perhaps it should be the populations of wealthy countries that we control and not those of poor countries. To use Hardin's logic, in order to protect the world's resources for future generations our duty might well be to sink the lifeboats, or at least to reduce the comfort in which the wealthy travel, and insist that all live at a sustainable level. Population control amongst the poor might still be necessary, but this does not mean that strict control of resource consumption amongst the wealthy is unnecessary. See also DOI: $10.1038 /$ npg.els.0002143.

\section{Population control and reproductive rights}

This issue of discriminating between rich and poor with regard to population control is not a mere hypothetical concern in Hardin's apocalyptic vision, but a real issue when considering population and global justice. Currently the issue of population control - and its justification as a public policy - is very different depending on context. For instance, some populations, generally those of minorities and poor communities, are presented as being 'out of control' and in need of reduction (Hardin 1974, p.565). For example, Amartya Sen has noted that many aside from Hardin draw attention to the fact that approximately $90 \%$ of global population growth between 1984 and 1994 occurred in poor countries (Sen 1994, p.63), or that of the 923 million people born in the $1980 \mathrm{~s}$, over half (517 million) were born in Asia (Sen 1994, p.63). However, as mentioned above, he also notes that development, economic aid, and improvements to social welfare systems are also effective tools at reducing birth rates in poor countries (Sen 1994, p.72). Meanwhile, wealthier groups are usually more concerned with the decline of fertility (Freedman 1961, p.53; Sauer et al. 1992, p.1275) and considerable effort has been expended in analyzing the causes of declines in fertility. For example, as Ahn and Mira have noted, between 1970 and 1995 as more women in countries belonging to the Organization for Economic Cooperation and Development (OECD) became more engaged in the workforce, fertility rates declined in those countries (Ahn and Mira 2002, p.667). Similarly, Adserà has found that even in relatively prosperous nations in Europe, fertility rates can be affected by trends in employment law, with fertility rates in countries in southern Europe, where employment contracts tend to be shorter term, being lower than in Scandinavian countries where there are greater social support systems in place (Adserà 2004, pp.17-18). Similarly, the issue of aging populations in wealthy countries, and the extra medical resources consumed by the elderly, receives a great deal of analysis

\footnotetext{
${ }^{3}$ In this example group one consumes twice as many resources, despite the fact that it is half the size in terms of the number of individuals, than group two.
} 
This is the final accepted version of this paper - please do not cite.

For the final published version, see West-Oram, P.G.N and Widdows, H. "Global Population and Global Justice: Equitable Distribution of Resources Among Countries", Electronic Library of Science (eLS), 2012. URL = http://dx.doi.org/10.1002/9780470015902.a0024140

(Stewart et al. 2003, pp.52-53; Angus et al. 2000, pp.2766-2767). See also DOI: 10.1038/npg.els.0003965.

There are obviously double standards in place when discussing global population control measures. Hartmann for example, argues that those who argue for population control do so extremely selectively - 'Upper- and middle-class people have the right to voluntary choice as to whether and when to bear children, but the rights of poor people are subordinate to the overriding imperative of population control' is the claim Hartmann attributes to the modern Malthusian (Hartmann 1995, p.15). Whereas, in poorer countries the emphasis is on encouraging women to have fewer children (Sen 1990; Hartmann 1995, p.15; Watts 2005; Ebenstein 2010) - something which is often not in their best interest if they live in a society where women's status is determined by motherhood or where children provide the only source of security and support in old age (Hellsten 2002, pp.48-49). Conversely in the developed world there is concern about falling reproductive rates and about how to support a growing elderly population (Angus et al. 2000) and the ethics of the increasing use of technology to enable women to have children who cannot conceive without assistance (Dyson 1995; Warnock 2002, pp.15-16). For example, either through the use of In Vitro Fertilization (IVF) (Shenfield 2002) or, theoretically at least, human cloning (Sunstein 2002, pp.1-2). See also DOI: 10.1002/9780470015902.a0005200.pub2, DOI: 10.1002/9780470015902.a0005185.pub2, and DOI: 10.1002/9780470015902.a0005592.pub2.

If population control in some form can be justified ethically as a reasonable way of addressing scarce resources then one needs to consider the ethics of how it is done. For instance, what, if any, level of force or coercion is permissible? In addition, such policies raise gender issues - which are too often ignored in this debate - since reproductive rights are fundamentally connected to a women's right over her body. Population control will always fall disproportionately on women rather than men, as rights to reproduce are connected to rights to bodily integrity. This is not to say that men do not have interests in reproduction and of course certain of men's rights will be curtailed. For instance the right to form a family may be curtailed, but population control does not usually impact on men's rights of bodily integrity. However, it is worth noting that there are no reproductive rights as such, in that they are not named in the Universal Declaration of Human Rights (UDHR) or other rights documents. What is asserted is the right to found a family (article 16), and the importance of bodily integrity (article 5), which forbids torture and cruel or inhuman treatment and punishment (UN General Assembly 1948). Taken together, these rights can be used to claim that no one should be physically prevented from conceiving and bearing children; or conversely that no one should be forced to carry a child.

There are instances of both more and less overt and draconian forms of population control and practices include education, providing contraception, penalizing those who exceed government mandates on family size, ${ }^{4}$ abortion, and sterilisation. Practices of forced and coerced sterilisation are likely to be seen by most as unjustifiable infringements on bodily integrity (problematic even if one does not endorse reproductive rights) but have been used for example, to enforce the notorious one child policy in China (Ebenstein 2010, p.89).

\footnotetext{
${ }^{4}$ For example, by refusing access to public housing for families which contravene China's one child policy (Sen 1994, p.67) or imposing fines on multi child households (Watts 2005, p.1253).
} 
This is the final accepted version of this paper - please do not cite.

For the final published version, see West-Oram, P.G.N and Widdows, H. "Global Population and Global Justice: Equitable Distribution of Resources Among Countries", Electronic Library of Science (eLS), 2012. URL = http://dx.doi.org/10.1002/9780470015902.a0024140

Forced sterilisation is a risk when population control becomes judged as ethically acceptable or ethically required. Particularly controversial is the use of sterilisation where consent is coerced or compromised. Currently this occurs in Europe particularly scandalously with 'undesirable' ethnic groups; particularly 'gypsies' and adolescent or disabled women (Zampas and Lamačková 2011, pp.163-165). ${ }^{5}$ The continuation of coerced sterilisation practices of Roma women in Europe was brought to light in a now famous report, Body and Soul: Forced Sterilization and Other Assaults on Roma Reproductive Freedom (Center for Reproductive Rights et al. 2003). This report described continuing practices of forced sterilisation in Slovakia, although the practice is not limited to Slovakia and has since been documented in many other countries. The report documents sterilisation as a common experience of Roma women. In these instances women go into hospital when in labour, then, when about to be given a caesarean section they are told to sign a consent form. This form gives consent not only to a caesarean section, but also to tubal ligation. ${ }^{6}$ In some cases women are not informed that they have signed a form 'consenting' to their sterilization until after the procedure has taken place, thereby rendering any 'consent' given meaningless (Center for Reproductive Rights et al. 2003, pp.51-52).

Similarly, in April 2010, Amnesty International reported that according to Chinese media reports, 'officials in Puning City, Guangdong Province aim to sterilize 9,559 people, some against their will, by 26 April' in order to comply with the family planning targets based on China's 'one child' policy (Amnesty International UK 2010). ${ }^{7}$ As noted in the Zampas and Lamačková article mentioned above, there is also a history of such practices in Europe, going back to the atrocities committed by the Nazi regime during the 1930s and 40s. In their paper they note that in many cases women from vulnerable groups who are in the advanced stages of labor are often advised to 'consent' to sterilisation for their own future good based on little or no information, or opportunity to ask questions or object (Zampas and Lamačková 2011, pp.163-165). This brief discussion shows the dangers that endorsing population control can have for vulnerable groups - on women, poor women, and women from disadvantaged groups.

When population control measures are enforced it tends to be female children who are abandoned or female fetuses aborted (Hudson and Den Boer 2005, p.20; Tucker et al. 2005, p.540; The United Nations 2011a, p.66). For example, Amartya Sen argues that given the usual proportions of girls born compared to boys, and the fact that women tend to live longer when given equal medical treatment we can examine actual demographic data and see that there are roughly 100 million fewer women globally than there 'should' be, assuming equal medical and prenatal treatment (Sen 1990). At least some of these 'missing' 100 million women can be accounted for by inequitable and discriminatory health care practices whereby males receive preferential treatment in many cases, but there is also an increased incidence rate of female specific abortion and infanticide in many parts of the world (The United Nations 2011a, p.66). Similarly, Ebenstein has found a significant bias towards male children in gender ratios in China and has argued that this shift in gender ratios is the result of China's infamous 'one child policy'(Ebenstein 2010, pp.87-88). Of course, there may well be good

\footnotetext{
5 'Gypsies' is a general term to include many Roma ethnic groups, usually from central and eastern Europe.

${ }^{6}$ Tubal ligation is a form of female sterilisation by which the fallopian tubes are occluded, it is the most common form of birth control in the world (Center for Reproductive Rights et al. 2003, p.51).

${ }^{7}$ See also Watts (2005) for other examples of forced sterilisations in China.
} 
This is the final accepted version of this paper - please do not cite.

For the final published version, see West-Oram, P.G.N and Widdows, H. "Global Population and Global Justice: Equitable Distribution of Resources Among Countries", Electronic Library of Science (eLS), 2012. URL = http://dx.doi.org/10.1002/9780470015902.a0024140

reasons for placing limits on population growth since, for all the problems with Hardin's lifeboat argument, he does draw attention to the fact that we live in a world of limited resources, and the impact of rapid consumption of scarce resources by growing populations can be severe, as mentioned above. However, even if there are ethical reasons for population control particular attention must be given to the methods to ensure that the injustice of the means does not compromise the justice of the ends.

\section{Conclusion}

The ethical and justice concerns involved in addressing scarce resources by the means of population control are complicated. Importantly, any solution will also be highly complex. It is not the case that the global population can simply be reduced and that therefore there would be more resources to be shared and that the global issues of sustainability, environmental degradation, and resource distribution would be addressed. Here the goal of development is in some conflict with the goals of sustainability and preserving resources for future generations. This issue is particularly stark when considered in light of the vast disparity between the resources used by US citizens and their poor counterparts in the developing world. Moreover, and importantly, the sterilisation discussion shows that the politics of population control is often not what it seems. If it were, there would little focus on increasing population in areas where it is declining or a focus on reducing the fertility of certain groups; instead all would be treated equally. As it is, the debate surrounding population control frequently discriminates against the most vulnerable and emphasises an 'us versus them' mentality rather than focusing on collective solutions to a truly global problem.

Given this history of discrimination and human rights abuses it therefore seems rash to endorse any form of population control which might be used as a means to carry out other agendas or justify exploitative practice. For instance, discrimination against specific ethnic or economic groups (as is arguably done when programmes of population control are only enforced in the developing world or in a certain group) fails to treat the question of global population control as a global issue and instead defines it as a problem caused by a particular group. That is, rather than any population crisis being an issue for everyone, it is frequently defined as something caused by the irresponsible actions of vulnerable 'out-groups'. This said reducing population is likely to have ethically good consequences in terms of reducing humanity's impact on the environment and improving the equitability of the distribution of resources - but any attempt should focus as much on 'rich women' seeking IVF as on poor women, and should recognise that it is 'rich' not 'poor' children who are the biggest 'threat' environmentally.

\section{Bibliography}

Adserà, A., 2004. 'Changing Fertility Rates in Developed Countries. The Impact of Labor Market Institutions'. Journal of Population Economics, 17(1), pp.17-43.

Ahn, N. \& Mira, P., 2002. 'A Note on the Changing Relationship Between Fertility and Female Employment Rates in Developed Countries'. Journal of Population Economics, 15(4), pp.667-682. 
This is the final accepted version of this paper - please do not cite.

For the final published version, see West-Oram, P.G.N and Widdows, H. "Global Population and Global Justice: Equitable Distribution of Resources Among Countries", Electronic Library of Science (eLS), 2012. URL = http://dx.doi.org/10.1002/9780470015902.a0024140

Amnesty International UK, 2010. 'China: Thousands at risk of force sterilisation'. Amnesty International UK. Available at:

http://www.amnesty.org.uk/news_details.asp?NewsID=18720 [Accessed May 22, 2012].

Angus, D. et al., 2000. 'Caring for the critically ill patient. Current and projected workforce requirements for care of the critically ill and patients with pulmonary disease: can we meet the requirements of an aging population?' JAMA, 284(21), pp.2762-70.

Barnett, J. \& Adger, W.N., 2003. 'Climate Dangers and Atoll Countries'. Climatic Change, 61(3), pp.321-337.

Center for Reproductive Rights, Centre for Civil and Human Rights \& Zoon, I., 2003. Body and Soul: Forced Sterilization and Other Assaults on Roma Reproductive Freedom in Slovakia, New York, USA: Center for Reproductive Rights. Available at: http://reproductiverights.org/en/document/body-and-soul-forced-sterilization-andother-assaults-on-roma-reproductive-freedom [Accessed May 28, 2012].

Coleman, J., 2011. 'World's 'seven billionth baby' is born'. The Guardian. Available at: http://www.guardian.co.uk/world/2011/oct/31/seven-billionth-baby-born-philippines [Accessed May 26, 2012].

Dyson, A., 1995. The Ethics of IVF, London and New York: Mowbray.

Ebenstein, A., 2010. 'The 'Missing Girls' of China and the Unintended Consequences of the One Child Policy'. Journal of Human Resources, 45(1), pp.87 -115.

Freedman, R., 1961. 'The Sociology of Human Fertility: a Trend Report and Bibliography'. Current Sociology, 10(2), pp.35-68.

Hardin, G., 2008. 'Lifeboat Ethics: The Case Against Helping the Poor'. In T. Pogge \& K. Horton, eds. Global Ethics: Seminal Essays. Paragon Issues in Philosophy. St. Paul, MN: Paragon House, p. 27.

Hardin, G., 1974. 'Living on a Lifeboat'. Bioscience, 24(10), pp.561-568.

Hardin, G., 1968. 'The Tragedy of the Commons'. Science, 162, pp.1243-1248.

Hartmann, B., 1995. Reproductive Rights and Wrongs: The Global Politics of Population Control Revised ed., Boston, Massachusetts: South End Press.

Hellsten, S.K., 2002. 'Multicultural Issues in Maternal-Fetal Medicines'. In D. L. Dickenson, ed. Ethical Issues in Maternal-fetal Medicine. Cambridge, UK: Cambridge University Press, pp. 39-60.

Hudson, V.M. \& Den Boer, A.M., 2005. Missing Women and Bare Branches: Gender Balance and Conflict, Washington DC: Woodrow Wilson International Center for Scholars. Available at: http://www.wilsoncenter.org/sites/default/files/Hudson\%2526denBoer.pdf [Accessed May 25, 2012]. 
This is the final accepted version of this paper - please do not cite.

For the final published version, see West-Oram, P.G.N and Widdows, H. "Global Population and Global Justice: Equitable Distribution of Resources Among Countries", Electronic Library of Science (eLS), 2012. URL = http://dx.doi.org/10.1002/9780470015902.a0024140

Keister, L.A. \& Moller, S., 2000. 'Wealth Inequality in the United States'. Annual Review of Sociology, 26, pp.63-81.

McMichael, A.J., 1993. Planetary Overload: Global Environmental Change and the Health of the Human Species, Cambridge, UK: Cambridge University Press.

McMichael, A.J. et al. eds., 1996. Climate Change and Human Health: An Assessment Prepared by a Task Group on Behalf of the World Health Organization, the World Meteorological Organization and the United Nations Environment Programme, Geneva, Switzerland: World Health Organization.

McMichael, A.J. et al. eds., 2003. Climate Change and Human Health: Risks and Responses, Geneva, Switzerland: World Health Organization. Available at: http://www.who.int/globalchange/publications/climchange.pdf [Accessed November $22,2011]$.

Meinshausen, M. et al., 2009. 'Greenhouse-gas emission targets for limiting global warming to $2^{\circ} \mathrm{C}^{\prime}$. Nature, $458(7242)$, pp.1158-1162.

Murtaugh, P.A. \& Schlax, M.G., 2009. 'Reproduction and the carbon legacies of individuals'. Global Environmental Change, 19(1), pp.14-20.

Pogge, T., 2008. World Poverty and Human Rights Second ed., Cambridge, UK: Polity Press.

Sauer, M.V., Paulson, R.J. \& Lobo, R.A., 1992. 'Reversing the Natural Decline in Human Fertility: An extended Clinical Trial of Oocyte Donation to Women of Advanced Reproductive Age'. The Journal of The American Medical Association, 268(10), pp.1275-1279.

Sen, A., 1999. Development As Freedom, New York, USA: Knopf.

Sen, A., 1990. 'More Than 100 Million Women are Missing'. The New York Review of Books. Available at: http://www.nybooks.com/articles/archives/1990/dec/20/more-than-100million-women-are-missing/?pagination=false [Accessed May 22, 2012].

Sen, A., 1994. 'Population: Delusion and Reality'. New York Review of Books, 41(15), pp.6293.

Shenfield, F., 2002. 'Ethical Issues in Embryo Intervention and Cloning'. In Ethical Issues in Maternal-Fetal Medicine. Cambridge, UK: Cambridge University Press, pp. 149-166.

Stewart, S. et al., 2003. 'Heart failure and the aging population: an increasing burden in the 21 st century?' Heart, 89(1), pp.49-53.

Sunstein, C.R., 2002. 'Is There a Constitutional Right to Clone?' Available at: http://papers.ssrn.com/sol3/papers.cfm?abstract_id=304484 [Accessed May 24, 2012].

The United Nations, 2011a. Sex Differentials In Childhood Mortality, New York, USA: The United Nations. Available at: 
This is the final accepted version of this paper - please do not cite.

For the final published version, see West-Oram, P.G.N and Widdows, H. "Global Population and Global Justice: Equitable Distribution of Resources Among Countries", Electronic Library of Science (eLS), 2012. URL = http://dx.doi.org/10.1002/9780470015902.a0024140

http://www.un.org/esa/population/publications/SexDifChildMort/SexDifferentialsChil dhoodMortality.pdf.

The United Nations, 2011b. World Fertility Report 2009, New York, USA: The United Nations. Available at:

http://www.un.org/esa/population/publications/WFR2009_Web/Data/WFR2009_Rep ort.pdf [Accessed May 26, 2012].

The United Nations: Department of Economic and Social Affairs, 2011. World Population Prospects: The 2010 Revision - Highlights and Advance Tables, New York, USA: The United Nations. Available at: http://esa.un.org/unpd/wpp/Documentation/pdf/WPP2010_Highlights.pdf [Accessed May 26, 2012].

Tucker, J.D. et al., 2005. 'Surplus men, sex work, and the spread of HIV in China'. AIDS, 19(6). Available at:

http://journals.lww.com/aidsonline/Fulltext/2005/04080/Surplus_men,_sex_work,_an d_the_spread_of_HIV_in.1.aspx.

UN General Assembly, 1948. The Universal Declaration Of Human Rights, Paris, France: The United Nations. Available at: http://www.un.org/en/documents/udhr/index.shtml [Accessed November 10, 2011].

Warnock, M., 2002. Making Babies: Is There a Right to Have Children?, Oxford, UK: Oxford University Press.

Watts, J., 2005. 'Chinese officials accused of forcing abortions in Shangdong'. The Lancet, 366(9493), p.1253.

Widdows, H., 2011. Global Ethics: An Introduction, Durham: Acumen.

Zampas, C. \& Lamačková, A., 2011. 'Forced and coerced sterilization of women in Europe'. International Journal of Gynecology \& Obstetrics, 114(2), pp.163-166.

\section{eLS Cross References}

Butler, C.D., Powles, J. \& McMichael, A.J., 2001. Human Disease: Effects of Economic Development. In eLS. John Wiley \& Sons, Ltd. Available at: http://dx.doi.org/10.1002/9780470015902.a0003292.pub2.

Dickenson, D.L., 2001. Feminist Perspectives on Human Genetics and Reproductive Technologies. In eLS. John Wiley \& Sons, Ltd. Available at: http://dx.doi.org/10.1002/9780470015902.a0005592.pub2.

Evans, J.G., 2005. Ageing as a Global Challenge in the New Millennium. In eLS. John Wiley \& Sons, Ltd. Available at: http://onlinelibrary.wiley.com/advanced/search/results.

McCarty, J.P., Wolfenbarger, L.L. \& Wilson, J.A., 2001. Biological Impacts of Climate Change. In eLS. John Wiley \& Sons, Ltd. Available at: http://dx.doi.org/10.1002/9780470015902.a0020480. 
This is the final accepted version of this paper - please do not cite.

For the final published version, see West-Oram, P.G.N and Widdows, H. "Global Population and Global Justice: Equitable Distribution of Resources Among Countries", Electronic Library of Science (eLS), 2012. URL = http://dx.doi.org/10.1002/9780470015902.a0024140

Potts, M. \& Guillebaud, J., 2001. Population and Family Planning Programmes: Human Needs and Human Numbers. In eLS. John Wiley \& Sons, Ltd. Available at: http://dx.doi.org/10.1038/npg.els.0002143.

Pynes, C.A., 2001a. Human Cloning: Legal Aspects. In eLS. John Wiley \& Sons, Ltd. Available at: http://dx.doi.org/10.1002/9780470015902.a0005200.pub2.

Pynes, C.A., 2001b. In Vitro Fertilisation: Regulation. In eLS. John Wiley \& Sons, Ltd. Available at: http://dx.doi.org/10.1002/9780470015902.a0005185.pub2.

Raven, J.A., 2001. Global Change - Contemporary Concerns. In eLS. John Wiley \& Sons, Ltd. Available at: http://dx.doi.org/10.1038/npg.els.0003488.

\section{Further Reading}

Burns, W.C.G. \& Osofsky, H.M. eds., 2009. Adjudicating Climate Change: State, National, and International Approaches, Cambridge, UK; New York: Cambridge University Press.

Dasgupta, P., 1993. An Inquiry into Well-Being and Destitution, New York, USA: Oxford University Press.

Fogel, R.W., 2004. The Escape From Hunger and premature Death, 1700-2100: Europe, America, and the Third World, Cambridge, UK: Cambridge University Press.

Hudson, V.M. \& Den Boer, A.M., 2004. Bare Branches: The Security Implications of Asia'a Surpus Male Population, Cambridge, MASS: The MIT Press.

O’Neill, O., 1986. Faces of Hunger: an Essay on Poverty, Justice, and Development, London, UK: G. Allen \& Unwin.

Price-Smith, A.T., 2002. The Health of Nations: Infectious Disease, Climate Change, and their Effects on National Security and Development, Cambridge, MASS: The MIT Press.

Sen, A., 2004. The Standard of Living, Cambridge, UK: Cambridge University Press.

Singer, P., 1972. Famine, Affluence, and Morality. Philosophy and Public Affairs, 1(3), pp.229-243.

Widdows, H., 2011. Global Ethics: An Introduction, Durham: Acumen.

\section{Glossary}

Birth Rate - refers to the number of live births amongst a given population, for example a specific country or even the world, per 1000 people.

Carbon Emissions - Carbon Dioxide is one of many 'greenhouse gases' which contribute to global warming. The carbon emissions of a person, activity, process or machine refers to the amount of carbon dioxide emitted into the atmosphere by that event. For example, a person's 
This is the final accepted version of this paper - please do not cite.

For the final published version, see West-Oram, P.G.N and Widdows, H. "Global Population and Global Justice: Equitable Distribution of Resources Among Countries", Electronic Library of Science (eLS), 2012. URL = http://dx.doi.org/10.1002/9780470015902.a0024140

total life carbon emissions refer to the sum of the emissions caused by that person's behaviour and existence during the course of their life.

Developed World - Like developing countries, developed countries self-identify, though they are generally industrialised, wealthy and often hold more economic and political power than, typically poorer, developing countries.

Developing World - The World Trade Organisation does not have specific criteria for classifying a particular country as developing or developed, individual countries instead selfclassify, subject to approval by other member countries. However, being classified as a developing country generally means that a country is poorer than developed countries, with less developed infrastructure and industry.

Draconian - particularly strict, restrictive, or even disproportionate. Therefore, if a law is draconian it is exceptionally harsh or limiting and the punishment for breaking it may be extremely severe.

Informed Consent - An important concept for bioethics, informed consent is one of several key criteria by which the ethical status of a particular event is judged. Informed consent occurs when a person voluntarily agrees to a particular procedure or course of events when they are competent and have full knowledge of what will be done and the possible outcomes of the event.

Zero-Sum Game - refers to situations where one person's (or group of persons) loss or gain of benefit or welfare is balanced by an equal gain or loss of benefit by another person or persons. Zero-sum games therefore create no increase or loss of general good or benefit, since the good in question is merely transferred between participants, the total amount of good in the situation remains the same.

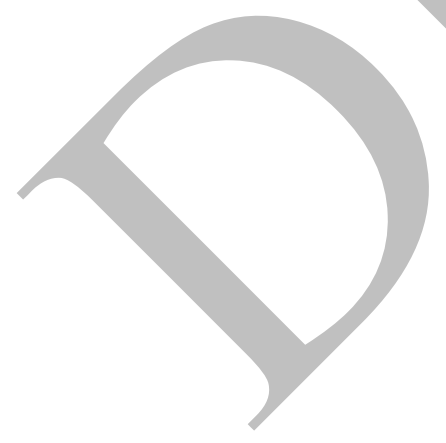

